\title{
Kejadian Demam Neutropenia pada Anak dengan Keganasan
}

\author{
Sarah Rafika Nursyirwan, Endang Windiastuti \\ Departemen Ilmu Kesehatan Anak Fakultas Kedokteran Universitas Indonesia-Rumah Sakit Cipto Mangunkusumo, Jakarta
}

Latar belakang. Demam merupakan salah satu manifestasi awal dari infeksi berat, terutama selama periode neutropenia. Infeksi menjadi penyebab utama morbiditas dan mortalitas pada pasien kanker. Data mikroorganisme tersering beserta sensitivitasnya dapat memberikan pola dan menjadi petunjuk tata laksana pasien anak dengan demam neutropenia.

Tujuan. Mengetahui kejadian demam neutropenia pada pasien anak dengan keganasan.

Metode. Penelitian potong lintang retrospektif dilakukan pada 65 pasien usia 0-18 tahun dengan penyakit keganasan yang dirawat di Departemen Kesehatan Anak, RSCM Jakarta dalam kurun waktu satu tahun sejak 1 April 2015 sampai dengan 30 April 2016. Diagnosis keganasan ditegakkan berdasarkan aspirasi sumsum tulang atau biopsi tumor. Dilakukan pengumpulan dan analisis data kejadian demam neutropenia, kejadian infeksi, serta pola sensitivitas antibiotik dari isolat patogen.

Hasil. Keganasan darah (LLA dan LMA) lebih sering ditemukan daripada tumor padat. Dalam satu tahun terjadi 83 episode rawat karena demam neutropenia. Bakteremia tersering disebabkan oleh bakteri Gram positif (6,4\%) dibandingkan Gram negatif (5,7\%). Hasil kultur dari sampel darah, urin, tinja, sputum, dan apusan luka tersering adalah steril $(55,2 \%)$. Luaran pasien demam neutropenia yang meninggal tersering didapatkan pada pasien LMA (18,8\%), LLA (17,2\%), rabdomiosarkoma (12,5\%), limfoma maligna non Hodgkin (LMNH) (10\%), diikuti tumor padat lainnya. Sensitivitas antibiotik tertinggi didapatkan pada vankomisin.

Kesimpulan. kejadian demam neutropenia lebih sering terjadi pada pasien dengan keganasan darah. Patogen ditemukan pada sebagian pasien dengan demam neutropenia. Penyebab terbanyak bakteremia adalah bakteri Gram positif. Sensitivitas antibiotik tertinggi didapatkan pada vankomisin. Data mengenai pola sensitivitas antibiotik terbaru diperlukan untuk pedoman tata laksana pasien demam neutropenia. Sari Pediatri 2017;19(4):220-5

Kata kunci: demam, neutropenia, keganasan, anak, infeksi

\section{Incidence of Febrile Neutropenia in Pediatric Patients with Malignancies}

Sarah Rafika Nursyirwan, Endang Windiastuti

Backgrounds. Fever is one of the early manifestations of severe infections, especially during periods of neutropenia. Infection is a major cause of morbidity and mortality in malignancy. Data on microorganisms and their sensitivity could provide patterns and clues to manage patients with febrile neutropenia.

Objectives. To report the incidence of febrile neutropenia in pediatric patients with malignancies.

Methods. A cross-sectional retrospective study was performed on 65 patients aged 0 to 18 years with malignancies who were treated at the Department of Child Health, RSCM Jakarta within a period of 1 year from April 2015 to April 2016. The diagnosis of malignancy was confirmed by bone marrow aspiration or tumor biopsy. Data on the incidence of febrile neutropenia, the incidence of infection, and antibiotics sensitivity patterns of the pathogen was collected and analyzed.

Results. Febrile neutropenia was more common in patients with hematologic malignancies (ALL and AML) than solid tumors. Within 1 year, there were 83 episodes of febrile neutropenia. Bacteremia was caused by Gram-positive bacteria (6.4\%) more than Gramnegative bacteria (5.7\%). Culture results from samples of blood, urine, feces, sputum, swabs were mainly sterile $(55.2 \%)$. Patients who died with febrile neutropenia were commonly seen on AML (18.8\%), ALL (17.2\%), rhabdomyosarcoma (12.5\%), non-Hodgkin lymphoma (10\%), followed by other solid tumors. The highest antibiotic sensitivity obtained was vancomycin.

Conclusions. Febrile neutropenia occurred more frequently in patients with hematologic malignancies. Pathogens were found in half of patients with febrile neutropenia. Bacteremia was caused mostly by Gram-positive bacteria. The highest antibiotic sensitivity obtained was vancomycin. Data on antibiotics sensitivity patterns were necessary for guiding the management of febrile neutropenia. Sari Pediatri 2017;19(4):220-5

Keywords: febrile, neutropenia, malignancy, child, infection

Alamat korespondensi: Dr. Sarah Rafika Nursyirwan Departemen Ilmu Kesehatan Anak, Fakultas Kedokteran Universitas Indonesia-Rumah Sakit Cipto Mangunkusumo, Jakarta, Jl. Salemba 6, Jakarta 10430, Indonesia. E-mail: sarah.rafika@gmail.com 
I nfeksi adalah penyebab utama morbiditas dan mortalitas pada pasien kanker. Demam terjadi pada sekitar sepertiga episode neutropenia pada pasien anak pasca kemoterapi atau setelah transplantasi sumsum tulang. Angka kejadian demam didapatkan 0,76 episode per 30 hari neutropenia. ${ }^{1}$

Penurunan morbiditas dan mortalitas karena infeksi terjadi karena penggunaan antibiotik empiris spektrum luas selama periode demam neutropenia. Hal ini merupakan kemajuan besar pada bidang onkologi pada tahun 1970. Studi-studi selanjutnya berhasil mengidentifikasi faktor risiko terjadinya infeksi dan menemukan terapi yang lebih terarah berdasarkan sensitivitas antibiotik.

Meskipun begitu, tata laksana pasien demam neutropenia masih menjadi masalah bagi petugas medis. Oleh karena hasil kultur dan sensitivitas baru akan tersedia setelah beberapa hari, penting bagi tiap institusi kesehatan mengetahui patogen yang predominan di tempatnya dan tingkat sensitivitas terhadap berbagai antibiotik. Data isolat mikroorganisme tersering beserta sensitivitasnya dapat memberikan pola dan menjadi petunjuk di kemudian hari untuk tata laksana pasien anak dengan demam neutropenia.

Tujuan penelitian ini adalah mengetahui kejadian demam neutropenia, mengidentifikasi patogen yang menyebabkan infeksi pada pasien demam neutropenia dengan keganasan serta mengetahui pola sensitivitas antibiotik di Rumah Sakit Cipto Mangunkusumo (RSCM).

\section{Metode}

Desain penelitian potong lintang retrospektif, yaitu dengan mengidentifikasi patogen penyebab infeksi pada demam neutropenia serta pola sensitivitas antibiotik. Penelitian dilakukan di Departemen Ilmu Kesehatan Anak FKUI-RSCM di bangsal kelas III non infeksi sejak April 2015 sampai April 2016 yang memenuhi kriteria inklusi penelitian.

Populasi terjangkau adalah pasien anak dengan demam neutropenia pasca kemoterapi yang dirawat di Departemen Ilmu Kesehatan Anak FKUI-RSCM. Data sampel diambil secara retrospective sampling dari data rekam medik pasien. Sampel penelitian adalah pasien anak usia 0 sampai 18 tahun dengan demam neutropenia pada keganasan darah dan tumor padat pasca kemoterapi.
Kriteria inklusi adalah pasien anak (usia 0 tahun-18 tahun) demam neutropenia pasca kemoterapi, telah didiagnosis keganasan, dan diperoleh data rekam medik yang lengkap. Kriteria eksklusi adalah bila data rekam medik tidak lengkap dan pasien dalam perawatan paliatif.

Diagnosis keganasan dibagi menjadi leukemia dan tumor padat. Leukemia ditegakkan berdasarkan aspirasi sumsum tulang, sedangkan tumor padat ditegakkan berdasarkan biopsi dan pemeriksaan patologi anatomi.

Neutropenia didefinisikan sebagai jumlah neutrofil absolut kurang dari $1000 \mathrm{sel} / \mu \mathrm{L}$. Jumlah neutrofil absolut dihitung menggunakan formula:

Jumlah leukosit absolut $(\mathrm{sel} / \mu \mathrm{L})$ x jumlah neutrofil dalam persentase $\div 100$.

Demam didefinisikan sebagai suhu tubuh $>38^{\circ} \mathrm{C}$ berdasarkan pemeriksaan di aksila. Pasien mengalami infeksi bila (1) terdapat tanda-tanda infeksi secara klinis meskipun tidak ditemukan kuman patogen (termasuk bakteremia) pada pameriksaan mikrobiologi atau (2) adanya kuman patogen pada pemeriksaan mikrobiologi dengan atau tanpa adanya tanda-tanda infeksi secara klinis. Pemeriksaan mikrobiologi adalah pemeriksaan kultur spesimen tubuh yang dapat berasal dari darah, urin, tinja, sputum, dan apusan luka.

Penelitian ini mendapat persetujuan etik penelitian dari Komisi Etik Penelitian Fakultas Kedokteran Universitas Indonesia.

\section{Hasil}

Dalam periode April 2015 sampai April 2016 didapatkan 65 pasien anak usia 0 sampai 18 tahun dengan demam neutropenia pada keganasan. Satu pasien dengan demam neutropenia dapat dirawat lebih dari satu kali episode (rerata 1, minimal 1, maksimal 3) sehingga didapatkan total perawatan 83 episode untuk seluruh pasien tersebut.

Diagnosis keganasan tersering pada demam neutropenia adalah keganasan darah diikuti oleh berbagai tumor padat pada anak (Tabel 1). Di antara 65 pasien, diperiksa 288 sampel kultur yang berasal dari sampel darah, urin, tinja, sputum, dan apusan luka untuk mencari patogen penyebab demam neutropenia. Hasil kultur tersering adalah steril $(55,2 \%)$, patogen tersering berupa Enterococcus faecalis (13,2\%), Escherichia coli (5,9\%), Klebsiella pneumoniae (5,2\%), Staphylococcus epidermidis (3,1\%), Klebsiella oxytoca 
Tabel 1. Diagnosis keganasan

\begin{tabular}{lc}
\hline Diagnosis & $\begin{array}{c}\text { Jumlah episode demam } \\
\text { neutropenia }(\mathrm{n}, \%)\end{array}$ \\
\hline LLA & $29(34,9)$ \\
LMA & $16(19,3)$ \\
LMNH & $10(12)$ \\
Osteosarkoma & $8(9,6)$ \\
Rabdomiosarkoma & $8(9,6)$ \\
Retinoblastoma & $3(3,6)$ \\
Hepatoblastoma & $3(3,6)$ \\
Tumor yolk sac & $2(2,4)$ \\
Neuroblastoma & $2(2,4)$ \\
Tumor Wilms & $1(1,2)$ \\
Tumor neuroendokrin & $1(1,2)$ \\
\hline Total & $83(100)$ \\
\hline
\end{tabular}

*LLA: leukemia limfoblastik akut, LMA: leukemia mieloblastik akut, LMNH: linfoma maligna non Hodgkin
(1,7\%), dan lainnya (15,7\%) (Tabel 2). Bakteremia tersering disebabkan oleh bakteri Gram positif $(6,4 \%)$ dibandingkan Gram negatif (5,7\%).

Pola sensitivitas antibiotik menunjukkan sensitivitas tertinggi terhadap vankomisin $(96,8 \%)$, teikoplanin $(96,4 \%)$, linezolid $(91,7 \%)$, sefoksitin (90,9\%), fosfomisin (85,7\%) (Gambar 1).

Patogen didapatkan pada 17 dari 141 sampel kultur darah (12,1\%), 80 dari 114 sampel kultur urin (70,2\%), 19 dari 19 sampel kultur tinja (100\%), 5 dari 5 sampel kultur sputum (100\%), 8 dari 9 sampel kultur apusan luka $(88,9 \%)$.

Luaran pasien demam neutropenia yang meninggal tersering didapatkan pada pasien LMA $(18,8 \%)$, LLA (17,2\%), rabdomiosarkoma (12,5\%), limfoma maligna non Hodgkin (LMNH) (10\%), diikuti tumor padat lainnya.

Tabel 2. Hasil kultur berdasarkan sampel kultur

\begin{tabular}{|c|c|c|c|c|c|c|c|c|c|c|c|c|}
\hline \multirow[t]{2}{*}{ Patogen } & \multicolumn{2}{|c|}{ Darah } & \multicolumn{2}{|c|}{ Urin } & \multicolumn{2}{|c|}{ Tinja } & \multicolumn{2}{|c|}{ Sputum } & \multicolumn{2}{|c|}{ Apusan luka } & \multicolumn{2}{|c|}{ Total } \\
\hline & $\mathrm{n}$ & $\%$ & $\mathrm{n}$ & $\%$ & $\mathrm{n}$ & $\%$ & $\mathrm{n}$ & $\%$ & $\mathrm{n}$ & $\%$ & $\mathrm{n}$ & $\%$ \\
\hline Steril & 124 & 87,9 & 34 & 29,8 & 0 & 0 & 0 & 0 & 1 & 11,1 & 159 & 55,2 \\
\hline \multicolumn{13}{|l|}{ Bakteri Gram positif } \\
\hline Staphylococcus epidermidis & 4 & 2,8 & 4 & 3,5 & 0 & 0 & 0 & 0 & 1 & 11,1 & 9 & 3,1 \\
\hline Staphylococcus aureus & 3 & 2,1 & 1 & 0,9 & 0 & 0 & 0 & 0 & 0 & 0 & 4 & 1,4 \\
\hline Enterococcus faecalis & 1 & 0,7 & 32 & 28,1 & 5 & 26,3 & 0 & 0 & 0 & 0 & 38 & 13,2 \\
\hline Bacillus sp & 1 & 0,7 & 0 & 0 & 0 & 0 & 0 & 0 & 0 & 0 & 1 & 0,3 \\
\hline Staphylococcus saprophyticus & 0 & 0 & 2 & 1,8 & 0 & 0 & 0 & 0 & 1 & 11,1 & 3 & 1,0 \\
\hline Streptococcus alfahemolytic & 0 & 0 & 2 & 1,8 & 0 & 0 & 0 & 0 & 0 & 0 & 2 & 0,7 \\
\hline MRSE & 0 & 0 & 0 & 0 & 0 & 0 & 1 & 20,0 & 0 & 0 & 1 & 0,3 \\
\hline Streptococcus viridans & 0 & 0 & 0 & 0 & 0 & 0 & 1 & 20,0 & 0 & 0 & 1 & 0,3 \\
\hline \multicolumn{13}{|l|}{ Bakteri Gram negatif } \\
\hline Escherichia coli & 2 & 1,4 & 12 & 10,5 & 3 & 15,8 & 0 & 0 & 0 & 0 & 17 & 5,9 \\
\hline Pseudomonas aeruginosa & 2 & 1,4 & 3 & 2,6 & 0 & 0 & 0 & 0 & 0 & 0 & 5 & 1,7 \\
\hline Klebsiella pneumoniae & 1 & 0,7 & 7 & 6,1 & 6 & 31,6 & 0 & 0 & 1 & 11,1 & 15 & 5,2 \\
\hline Acinetobacter lwoffii & 1 & 0,7 & 2 & 1,8 & 0 & 0 & 0 & 0 & 0 & 0 & 3 & 1,0 \\
\hline Salmonella sp & 1 & 0,7 & 0 & 0 & 0 & 0 & 0 & 0 & 0 & 0 & 1 & 0,3 \\
\hline Acinetobacter baumannii & 1 & 0,7 & 1 & 0,9 & 0 & 0 & 2 & 40,0 & 0 & 0 & 4 & 1,4 \\
\hline Klebsiella oxytoca & 0 & 0 & 2 & 1,8 & 3 & 15,8 & 0 & 0 & 0 & 0 & 5 & 1,7 \\
\hline Enterobacter aerogenes & 0 & 0 & 0 & 0 & 2 & 10,5 & 0 & 0 & 3 & 33,3 & 5 & 1,7 \\
\hline Proteus mirabilis & 0 & 0 & 3 & 2,6 & 0 & 0 & 0 & 0 & 2 & 22,2 & 5 & 1,7 \\
\hline Enterobacter sp & 0 & 0 & 1 & 0,9 & 0 & 0 & 0 & 0 & 0 & 0 & 1 & 0,3 \\
\hline Proteus vulgaris & 0 & 0 & 1 & 0,9 & 0 & 0 & 0 & 0 & 0 & 0 & 1 & 0,3 \\
\hline Enterobacter cloacae & 0 & 0 & 1 & 0,9 & 0 & 0 & 1 & 20,0 & 0 & 0 & 2 & 0,7 \\
\hline Acinetobacter sp & 0 & 0 & 1 & 0,9 & 0 & 0 & 0 & 0 & 0 & 0 & 1 & 0,3 \\
\hline \multicolumn{13}{|l|}{ Fungi } \\
\hline Candida tropicalis & 0 & 0 & 2 & 1,8 & 0 & 0 & 0 & 0 & 0 & 0 & 2 & 0,7 \\
\hline Candida albicans & 0 & 0 & 3 & 2,6 & 0 & 0 & 0 & 0 & 0 & 0 & 3 & 1,0 \\
\hline Total & 141 & 100 & 114 & 100 & 19 & 100 & 5 & 100 & 9 & 100 & 288 & 100 \\
\hline
\end{tabular}

*MRSE: methicillin-resistant Staphylococcus epidermidis 


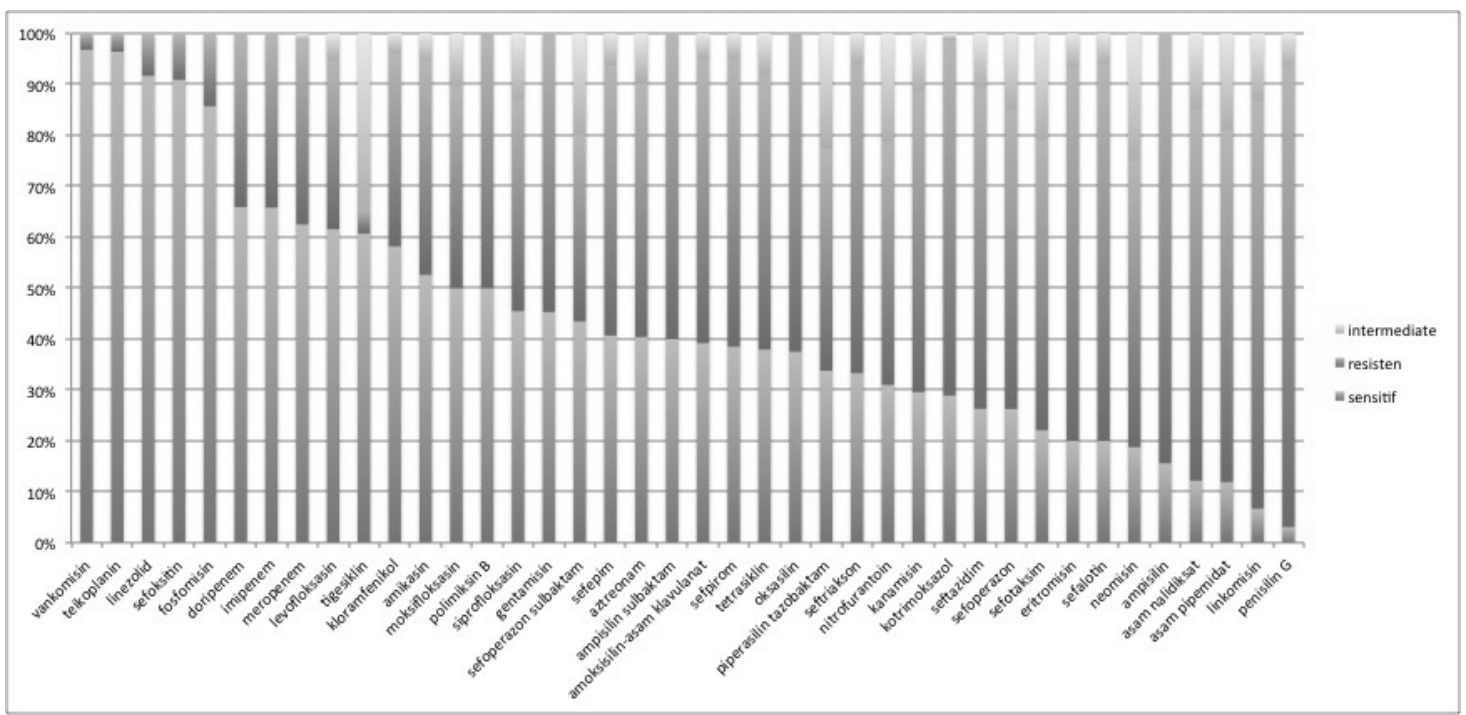

Gambar 1. Pola sensitivitas antibiotik

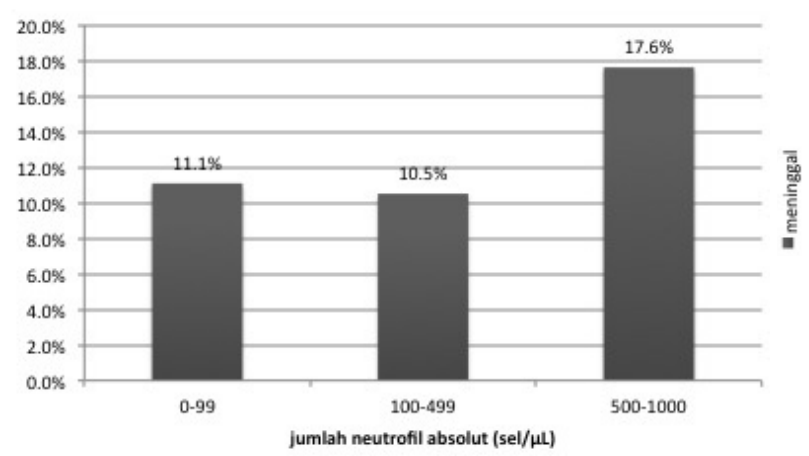

Gambar 2. Luaran pasien meninggal berdasarkan jumlah neutrofil absolut saat masuk perawatan

Pasien dengan jumlah neutrofil absolut $<100 \mathrm{sel} /$ $\mu \mathrm{L}$, dengan luaran meninggal 5 dari 45 episode demam neutropenia. Pasien dengan jumlah neutrofil absolut 100-499 sel/ $\mu \mathrm{L}$, dengan luaran meninggal 2 dari 19 episode demam neutropenia. Pasien dengan jumlah neutrofil absolut 500-1000 sel $/ \mu \mathrm{L}$, dengan luaran meninggal 3 dari 17 episode demam neutropenia $(\mathrm{p}=0,858)($ Gambar 2).

\section{Pembahasan}

Infeksi merupakan penyebab utama morbiditas dan mortalitas pada pasien kanker. ${ }^{2}$ Demam merupakan salah satu manifestasi awal dari infeksi berat, terutama selama periode neutropenia. Demam terjadi pada sekitar sepertiga dari episode neutropenia pada anak dengan neutropenia yang disebabkan kemoterapi, infiltrasi sel keganasan pada sumsum tulang, atau setelah transplantasi sumsum tulang. ${ }^{1}$

Episode demam neutropenia terbanyak didapatkan pada keganasan darah LLA dan LMA (54,2\%), diikuti dengan tumor padat. Temuan tersebut serupa dengan studi oleh Sudewi dkk ${ }^{3}$ yang melaporkan 81,5\% demam neutropenia, terutama dialami oleh pasien leukemia akut (LLA dan LMA) dibandingkan tumor padat. Sementara Roguin $\mathrm{dkk}^{4}$ melaporkan demam neutropenia terbanyak dialami pada pasien leukemia (41\%).

Strategi penggunaan antibiotik empiris sangat memengaruhi luaran dari pasien dengan demam neutropenia. ${ }^{4}$ Strategi ini memerlukan data yang terus diperbarui dari pola sensitivitas patogen yang diisolasi dari tubuh pasien.

Angka kejadian infeksi yang dilaporkan bervariasi (berkisar antara 10\%-40\%) tergantung dari institusi dan keganasan yang mendasari. ${ }^{4,5}$ Hasil kultur positif didapatkan 44,8\%. Bakteri Gram positif dan Gram negatif seringkali ditemukan dalam darah anak dengan demam neutropenia. ${ }^{1,5}$ Patogen penyebab berbeda di tiap institusi. Patogen yang sering ditemukan dari kultur darah adalah bakteri Gram positif (6,4\%) dibandingkan Gram negatif (5,7\%). Selama beberapa dekade terakhir terdapat perubahan global berupa predominasi organisme Gram positif disebabkan penggunaan antibiotik profilaksis, kondisi lingkungan lokal, dan kateter intravena lama. ${ }^{6}$ 
Bakteremia didapatkan $12,1 \%$, lebih sedikit dibandingkan penelitian Adrieanta dkk, ${ }^{8}$ yaitu $17 \%$. Program pencegahan infeksi perlu terus dilaksanakan agar angka infeksi pada pasien keganasan dapat ditekan.

Bakteremia dengan patogen Gram positif tersering adalah Staphylococcus koagulase negatif, Streptococcus viridans, dan Staphylococcus aureus (termasuk S. aureus resisten dengan metisilin). ${ }^{1,5,8}$ Serupa pada penelitian ini didapatkan bakteri Gram positif tersering adalah Staphylococcus epidermidis (Staphylococcus koagulase negatif) dan Staphylococcus aureus. Sedangkan patogen Gram negatif tersering adalah Escherichia coli, Klebsiella sp, Pseudomonas sp, Acinetobacter sp, dan Enterobacter $s p .{ }^{1,5,8,7} \mathrm{Hal}$ tersebut juga serupa dengan yang didapatkan pada penelitian ini. Fungi, terutama Candida $s$, lebih sering ditemukan setelah pemberian antibiotik spektrum luas jangka panjang, tetapi terkadang dapat merupakan infeksi patogen primer. ${ }^{1}$ Peningkatan penggunaan profilaksis antifungal dapat menyebabkan perubahan distribusi isolat fungi. ${ }^{8}$

Rosenblum dkk ${ }^{11}$ melaporkan 18,4\% kultur darah inisial yang positif, sedangkan bila pada kultur darah inisial steril selanjutnya dilakukan pemeriksaan kultur darah kembali, didapatkan 10,9\% kultur darah positif. Risiko akan meningkat pada pasien dengan riwayat kultur darah positif atau dirawat lebih dari 48 jam sejak onset demam.

Pasien demam neutropenia dapat diklasifikasikan menjadi risiko rendah dan risiko tinggi berdasarkan tanda dan gejala yang dialami, jumlah neutrofil absolut, jenis keganasan, terapi yang diberikan, durasi neutropenia, dan kondisi komorbid lainnya. ${ }^{9}$ Namun, saat ini belum ada kategori stratifikasi risiko khusus pada anak yang disetujui bersama. ${ }^{10,11}$

Pasien dengan kriteria risiko tinggi dapat mengalami infeksi yang berat.

Pasien yang termasuk kategori risiko tinggi terdiri atas, ${ }^{11}$

- Neutropenia (hitung neutrofil absolut $<500 \mathrm{sel} /$ $\mu \mathrm{L})$ yang berlangsung lebih dari 7 hari

- Adanya insufisiensi hepar (kadar aminotransferase $>5$ kali nilai normal) atau insufisiensi renal (klirens kreatinin $<30 \mathrm{~mL} /$ menit)

- Kondisi komorbid:

- Hemodinamik tidak stabil

- Mukositis oral atau gastrointestinal yang mengganggu fungsi menelan atau menyebabkan diare

- Gejala gastrointestinal, termasuk nyeri abdo- men, mual, muntah, atau diare

- Perubahan neurologis atau status mental akut

- Infeksi kateter intravena

- Infiltrat paru yang baru atau hipoksemia atau penyakit paru kronik

- Pasien dengan leukemia limfoblastik akut pada bayi, leukemia mieloblastik akut, atau dalam 30 hari setelah transplantasi sumsum tulang

Tidak didapatkan perbedaan luaran pasien meninggal berdasarkan jumlah neutrofil absolut saat masuk perawatan. Data tersebut perlu diinterpretasi secara hati-hati karena jumlah sampel untuk tiap kategori jumlah neutrofil absolut tidak homogen. Macher dkk ${ }^{15}$ menyatakan bahwa memprediksi risiko infeksi bakteri yang berat pada demam neutropenia sulit karena banyaknya variabel yang turut berpengaruh untuk dilakukan analisis.

Pasien dengan risiko tinggi sebaiknya dirawat inap dan diberikan antimikroba empiris. Pasien dengan risiko rendah dapat dipertimbangkan pemberian terapi empiris oral atau perawatan rawat jalan.

Penelitian ini memiliki keterbatasan, yaitu jumlah subyek penelitian tidak homogen untuk kategori pasien risiko tinggi dan rendah.

\section{Kesimpulan}

Kejadian demam neutropenia lebih sering terjadi pada pasien dengan keganasan darah. Patogen ditemukan pada sebagian pasien dengan demam neutropenia. Penyebab terbanyak bakteremia adalah bakteri Gram positif. Sensitivitas antibiotik tertinggi didapatkan pada vankomisin.

\section{Daftar pustaka}

1. Castagnola E, Fontana V, Caviglia I, Caruso S, Faraci M, Fioredda F, dkk. A prospective study on the epidemiology of febrile episodes during chemotherapy-induced neutropenia in children with cancer or after hemopoietic stem cell transplantation. Clin Infect Dis 2007;45:1296-304.

2. Auletta JJ, O’Riordan MA, Nieder ML. Infections in children with cancer: a continued need for the comprehensive physical examination. J Pediatr Hematol Oncol 1999;21:501-8.

3. Sudewi NP, Tumbelaka AR, Windiastuti E. Kejadian demam neutropenia pada keganasan. Sari Pediatri 2007;8:68-72. 
4. Roguin A, Kasis I, Ben-Arush MW, Sharon R, Berant M. Fever and neutropenia in children with malignant disease. Pediatr Hematol Oncol 1996;13:503-10.

5. Hughes WT, Armstrong D, Bodey GP, Bow EJ, Brown AE, Calandra T, dkk. 2002 guidelines for the use of antimicrobial agents in neutropenic patients with cancer. Clin Infect Dis 2002;34:730-51.

6. Hakim H, Flynn PM, Knapp KM, Srivastava DK, Gaur AH. Etiology and clinical course of febrile neutropenia in children with cancer. J Pediatr Hematol Oncol 2009;31:623-9.

7. Ramphal R. Changes in the etiology of bacteremia in febrile neutropenic patients and the susceptibilities of the currently isolated pathogens. Clin Infect Dis 2004;39:25-31.

8. Adrieanta, Windiastuti E, Handryastuti S. Etiologi demam neutropenia pada anak dengan keganasan dan penggunaan skor klasifikasi Rondinelli. Sari Pediatri 2014;16:229-35.

9. Agyeman P, Aebi C, Hirt A, Niggli FK, Nadal D, Simon A, dkk. Predicting bacteremia in children with cancer and fever in chemotherapy-induced neutropenia: results of the prospective multicenter SPOG 2003 FN study. Pediatr Infect Dis J 2011;30:114-9.

10. Mor M, Gilad G, Kornreich L, Fisher S, Yaniv I, Levy I. Invasive fungal infections in pediatric oncology. Pediatr Blood
Cancer 2011;56:1092-7.

11. Rosenblum J, Lin J, Kim M, Levy AS. Repeating blood cultures in neutropenic children with persistent fevers when the initial blood culture is negative. Pediatr Blood Cancer 2013;60:923-7.

12. Freifeld AG, Bow EJ, Sepkowitz KA, Boeckh MJ, Ito JI, Mullen CA, dkk. Clinical practice guideline for the use of antimicrobial agents in neutropenic patients with cancer: 2010 update by the infectious diseases society of america. Clin Infect Dis 2011;52:56-93.

13. Phillips RS, Lehrnbecher T, Alexander S, Sung L. Updated systematic review and meta-analysis of the performance of risk prediction rules in children and young people with febrile neutropenia. PLoS One 2012;7:38300.

14. Lehrnbecher T, Phillips R, Alexander S, Alvaro F, Carlesse F, Fisher B, dkk. Guideline for the management of fever and neutropenia in children with cancer and/or undergoing hematopoietic stem-cell transplantation. J Clin Oncol 2012;30:4427-38.

15. Macher E, Dubos F, Garnier N, Delebarre M, Berranger ED, Thebaud E, dkk. Predicting the risk of severe bacterial infection in children with chemotherapy-induced febrile neutropenia. Pediatr Blood Cancer 2010;55:662-7. 